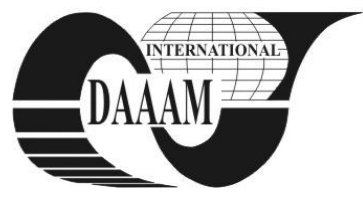

Annals of DAAAM for 2011 \& Proceedings of the 22nd International DAAAM Symposium, Volume 22, No. 1, ISSN 1726-9679 ISBN 978-3-901509-83-4, Editor B. Katalinic, Published by DAAAM International, Vienna, Austria, EU, 2011 Make Harmony between Technology and Nature, and Your Mind will Fly Free as a Bird

Annals \& Proceedings of DAAAM International 2011

\title{
POPULATION GROWTH AND HUMAN RESOURCES MANAGEMENT
}

\author{
SKALOVA, P[etra]
}

\begin{abstract}
This paper deals with population growth in the Czech Republic, with valuation of reasons of its current slow progress and with describing its impact on human resources management in organizations, mainly obtaining quality staff and their managing. In this paper is mentioned connection of population growth with qualification structure of population and their impact on human resources management. All macroeconomic factors connect very closely with each other and therefore it is not possible to overlook their increasing and their impact on behavior of particular companies. It is necessary to deal with them and to focus on their progress.

Key words: population growth, human resources management, company, pension reform
\end{abstract}

\section{INTRODUCTION}

To obtain qualified and efficient staff is one of the main activities of managers and Human Resources departments in every company. The need for such staff on the labor market depends on the character of companies and on the number of economically active population in each country, on their qualification structure and their lifestyle.

In the Czech Republic there is a very important problem that must be immediately solved especially by political changes, because it has a negative impact on everyday activities of companies and on the existing system of financing future pensions. The population growth is the main problem.

According to the statistical information, the Czech Republic is a country with very low fertility rate, which is the reason of the negative growth rate. Matt Rosenberg (2011) mentions: "the rate of national growth is commonly between about $0.1 \%$ and 3\% annually in other country. The Czech Republic and some other European countries growth rate is actually negative (on average, women in the Czech Republic give birth to 1.2 children, which is below the number to yield zero population growth, approximately 2.1 children). The Czech Republic's natural growth rate of -0.1 can not be used to determine doubling time because the population is actually shrinking in size."

The main reason why we need to solve these matters is preserving the long-term economic stability of the Czech Republic, and not deteriorating the living standard of Czech citizens.

\section{LOW POPULATION GROWTH}

The main causes of the low population growth were the changes in the lifestyle of citizens in postcomunistic countries in the 1990 s and at the beginning of the $20^{\text {th }}$ century.

The low population growth was caused mainly by changes in the political system and behavior of young people, who had more opportunities to travel and to continue their education because the number of high schools and universities in the Czech Republic was increasing. They could also study abroad. The young people at that time had different priorities. These were the reasons why young women who were born in 1970s postponed their giving birth to their first child until a relatively higher age. The next reason of the low population growth at the beginning of $21^{\text {st }}$ century was also the change of economic conditions. The number of newborn babies has increased slightly in the past years. This growth was encouraged by the government financial support, namely the birth grant and parental allowances in 2006 and 2007.

Due to the current low population growth, financing so many future pensioners in the future in the Czech Republic is jeopardized. This is because of the high population growth in the 1970. The low long-term population growth brings the necessity of extensive pension system reform, and also companies must make sure that they employ well-qualified and reliable staff with the right qualifications. This is the main task of human resources managers in the future.

The low population growth at the beginning of $21^{\text {th }}$ century and increasing number of secondary schools, high schools and universities after 1990 and the effort to maintain their running allow students to study various fields of their interests in the Czech Republic. The low population growth is connected with an adequate number of schools and their specializations. The number of these schools and their structure must correspond to the situation on the labor market. All schools are trying to achieve economic stability, which is nearly impossible because the number of potential students decreased in several last years. Majority of students often prefer to study at a specialized secondary school rather than at a vocational school. The total number of vocational school trainees is still decreasing and vocational schools have difficulties to cover their costs and two schools often join together or some schools are dissolved. This trend causes difficulties for companies to obtain a sufficient number of workers.

The supply and demand in the labor market is given by the structure of citizens and their qualifications, also by the structure of schools and their specialization, as well as by the total population growth that is necessary to maintain the sufficient number of economically active population. These aspects determine the work of human resources management in companies in the future, mainly with regard to recruiting their staff, their development, motivation, remuneration etc.

Due to these negative trends in the population growth and expected problems on the labor market, the government in the Czech Republic has proposed a new pension system. This pension system focuses on changes in the tax system, increase of retirement age and the overall financing of pensioners. The economic specialists stress the fact that "the pension system reform is a very difficult and complex task" (Bezděk, 2001) and it must be based on detailed and sophisticated models covering the whole range of pension system benefits.

At present, the government strives to increase the population growth and a number of potential job opportunities by the social support as well as by the active employment policy and it also supports international migration. 


\section{PENSION REFORM AND HUMAN RESOURCES MANAGEMENT}

All of the changes in the population structure mentioned above have had a huge impact on human resources management in companies. Managers will have to solve the following main tasks in the near future:

- Looking for staff having the required qualifications,

- necessity of cooperation between schools and companies,

- creating opportunities for students' practice,

- training programmes focused on talented students,

- creating companies' own vocational training centers depending on the company's needs for qualified and loyal workers,

- higher motivation of staff due to a decrease in employee turnover,

- multicultural organizations and management systems.

After implementation of the new pension system reform, there will be changes in the retirement age. The main disadvantages of these trends that will influence the human resources management are as follows:

- lower flexibility of older people,

- higher risk of illness,

- higher absenteeism due to health problems,

- less ability to do physical work,

- lower ability to make quick decisions

- lower mobility.

Although older people have more work experience, they are less able to learn new things, to change their habits or systems of their work than younger staff. Because of the seniority system in some companies, the human resources managers will have to respect expected higher wages in comparison with graduates.

All companies usually want return on money invested in their staff. They also use various motivation tools to preserve the number of staff and to stop the employee turnover. "All companies must realize that the workforce is crucial for their success and the way they treat their employees will influence their current and future costs, their competitive ability as well as their position in the market." (Skálová, 2008a)

In the future it will be necessary to introduce flexible working hours due to current trends in the population growth and also due to new changes in the pension system as well as the companies' effort to get qualified staff.

"Each company should realize which employees are needed for its activities. That is why the appropriate and well-timed employee planning is necessary. It is important to determine required qualifications of employees as well as their knowledge, skills and capability." (Skálová, 2009)

It is very important to find the connection between the state pension reform and requirements of individual companies as well as to find a suitable conception that could provide reliable and well-qualified staff that is able to do offered job. Cooperation between companies and secondary, vocational and high schools is also very important because they prepare future employees required on the market.

The necessity of the government reform and its impact on the population growth, pension system as well as the running of companies depends on the national economic conditions, possibilities to receive quality education, and on the political system.

The role of human resources managers is very important and future changes in pension system, mainly the higher retirement age, are bringing lots of problems with them. For older people, it is often very difficult to find an adequate job and to compete with more flexible younger progressive employees concerning their knowledge of modern technologies and new ways of problem solutions. On the other hand, we must also mention advantages of employing older people, such as their experience and knowledge of work environment.

„Each company needs to have the right staff in the right places at the right time. It is unquestionable that the quality of performance depends on the length of employee's experience, personal qualities as well as on their age influencing their physical and mental abilities.“ (Skálová, 2008b)

\section{CONCLUSION}

The aim of this paper is to show the main impact of the low population growth on the human resources management in companies, to describe the main problems associated with this situation and to propose the tools that should be used to solve it. This paper should help us understand the connection between individual macroeconomic factors and the population growth and show how the planned pension system reform could influence the situation on the labor market and managers' decision-making when selecting their employees.

It is necessary to know that the population growth is one of the most important factors which influence the economic stability of a country as well as the future employee structure in companies. The low population growth can have a long-time impact on the economy of individual companies as well as on the national economy, especially in a small country as the Czech Republic is. This problem must be solved not only by companies but also by the government.

This paper is a part of the development project called SYPROM - Innovation of the follow-up study programme with the emphases on the process and project management, which focuses on the development of education concerning the master's degree studies at the Faculty of Economics of the University of West Bohemia. It is also related to the author previous articles dealing with analyses of chosen macroeconomic factors and their connection with human resources management. It shows how important it is to analyze individual macroeconomic factors and their impact on corporate governance.

The conclusions of this paper will be used to develop and improve tuition in courses focusing on business and human resources management. They will also become a basis for her further research and publication activities.

\section{REFERENCES}

Bezděk, V. (2001). On one of Possible Scripts of Pension System Reform in the Czech Republic. Political Economy, Vol. 49, No. 2, (2/2001) ISSN 0032-3233. Prague

Rosenberg, M. (2011). Population Growth Rates and Doubling Time. Available from

http://geography.about.com/od/populationgeography/a/pop ulationgrow.thm Accessed: 2011-08-15

Skálová, P. (2008a). Business Ethics in Human Resource Management. In: Actual Manager's Trends in Theory and Praxis. Hittmár, Š., (Ed.), pp. 265 - 260, University of Žilina. ISBN 978-80-8070-966-2, Žilina, Slovakia

Skálová, P. (2008b). Education of Employees. In: New Trends and Challenges in Management, Weiss, E.; Bitkowska, A.; Godlewska, M., (Ed.), pp. 501-510, Vizja Press - IT, ISBN 978-83-61086-29-1,Warsaw, Poland,

Skálová, P. (2009). Impact of Globalization on the Human Resource Management in Organizations, Proceedings of Global Conference on Business and Finance, 2009-0527/30, San Jose, Costa Rica, ISBN1931-0285, Jalbert, T., (Ed.), pp. 493-498, The Institute for Business and Finance Research, San Jose 